\title{
Nucleoplasmic Calcium Buffering Sensitizes Human Squamous Cell Carcinoma to Anticancer Therapy
}

Lídia M. Andrade', Jony M. Geraldo², Osvaldo X. Gonçalves², Miguel T. T. Leite' ${ }^{2}$, Anderson M. Catarina², Melissa M. Guimarães ${ }^{3}$, Adriana F. Paes Leme ${ }^{4}$, Sami Yokoo4, Carlos R. Machado5, Matheus A. Rajão ${ }^{5}$, Sandhra M. Carvalho', Dawidson A. Gomes ${ }^{5}$, Carla J. Aguiar ${ }^{7}$, Elaine M. Souza-Fagundes ${ }^{7}$, Carlos L. Zani' ${ }^{1}$, Rodrigo R. Resende ${ }^{5}$, Olindo A. Martins-Filho ${ }^{1}$ and M. Fátima Leite, ${ }^{7,8 *}$

${ }^{1}$ René Rachou Research Center, Belo Horizonte, Brazil

${ }^{2}$ São Francisco Radiotherapy Institute, Belo Horizonte, Brazil

${ }^{3}$ Federal University of Vales do Jequitinhonha and Mucuri, Diamantina, Brazil

${ }^{4}$ National Laboratory of Biosciences, Campinas, Brazil

${ }^{5}$ Department of Biochemistry and Immunology, Federal University of Minas Gerais, Belo Horizonte, Brazil

${ }^{6}$ School of Engineering, Federal University of Minas Gerais, Belo Horizonte, Brazil

${ }^{7}$ Department of Physiology and Biophysics, Federal University of Minas Gerais, Belo Horizonte, Brazil

${ }^{8}$ Howard Hughes Medical Institute, USA

\begin{abstract}
Background: Calcium $\left(\mathrm{Ca}^{2+}\right)$ signaling within the nucleus is known to play a crucial role in cell proliferation. The aim of this study was to investigate whether nuclear $\mathrm{Ca}^{2+}$ buffering could improve the antitumor effect of $\mathrm{X}$-rays therapy on Human Squamous Cell Carcinoma (HSCC).

Methods: For these purpose, we developed an experimental protocol that simulated clinical radiotherapy and prevented bystander effects of irradiation. HSCC, A431 cell line, was submitted to 10 Gy cumulative X-rays therapy alone $\left(\mathrm{XR}_{\mathrm{Cd}} 10 \mathrm{~Gy}\right)$ or in association with the strategy that selectively buffer nuclear $\mathrm{Ca}^{2+}\left(\mathrm{Ca}^{2+}{ }_{n}\right)$ signaling.

Results: Upon $\mathrm{Ca}^{2+}{ }_{\mathrm{n}}$ buffering, A431 cell proliferation rate decreased significantly as compared to control. Cell cycle analysis showed that association of $\mathrm{Ca}^{2+}$ buffering with $\mathrm{XR}_{\mathrm{Cd}} 10 \mathrm{~Gy}$ increased the percentage of A431 cells at $\mathrm{G}_{2} / \mathrm{M}$ and did not increase nuclear/mitochondrial DNA damages. Nonetheless, $\mathrm{Ca}^{2+}{ }_{n}$ buffering prevented the increase of the radioresistance-related biomarker ADAM-17 expression and EGFR activation induced by irradiation. Furthermore, the association therapy almost completely abolished cell survival fraction even using approximately half of the X-rays cumulative dose.
\end{abstract}

Conclusions: Nuclear $\mathrm{Ca}^{2+}$ buffering sensitizes human squamous cell carcinoma to $\mathrm{X}$ - rays irradiation treatment.

Keywords: Human squamous cell carcinoma; Nuclear calcium buffering; X-rays irradiation; A431 cells; Head and neck tumor

\section{Introduction}

Head and neck cancer is the eighth leading cause of cancer death worldwide [1]. In patients diagnosed with head and neck cancer, Squamous Cell Carcinoma (SCC) is the most frequent tumor type, characterized by local tumor aggressiveness, and high frequency of second primary tumors [2]. Although, radiotherapy plays a pivotal role in head and neck SCC treatment, recurrent tumors frequently show increased radioresistance [3]. It is known for instance, that exposure of SCC to X-rays therapy triggers compensatory pathways that can induce cell survival and repopulation following radiation [4]. Therefore, for SCC, resistance to radiotherapy is one of the major barriers in the treatment [5], and little is known about the molecular and cellular mechanisms that leads to radioresistance. Moreover, the combined effects of radiation field uniformity and dose fractionation schedules on SCC have not been studied in detail [6]. One molecular target demonstrated to be important for the SCC treatment has been the Epidermal Growth Factor (EGF) [7]. EGF receptor (EGFR) exhibits tyrosine-kinase activity and through activation of its downstream signals regulates cell proliferation, differentiation and survival [8]. It has been demonstrated that EGFR is frequently over expressed in malignant tumors, and its over expression correlates with increased cellular resistance to consecutive radiation exposure [4,8]. Radiation activates EGFR, which in turn stimulates phospholipase C (PLC) activity, inositol-1,4,5-trisphosphate $\left(\mathrm{IP}_{3}\right)$ production and release of $\mathrm{Ca}^{2+}$ from internal stores [9]. Intracellular $\mathrm{Ca}^{2+}$ participates as a second messenger in several signaling pathways, coordinating key events in a variety of cellular functions [10]. Particularly, nuclear $\mathrm{Ca}^{2+}$ signaling is known to play an important role on tumor growth $[11,12]$. For instance, we had previously demonstrated that nuclear $\mathrm{Ca}^{2+}$ regulates the expression of genes involved in cell proliferation, and also showed that the buffering of nuclear $\mathrm{Ca}^{2+}$ impairs the growth of cancer cells in vitro as well as in vivo [11,12]. Nevertheless, there is no report regarding the cellular effect of nuclear $\mathrm{Ca}^{2+}$ buffering associated to X-rays on cell proliferation. In the present work, we investigated whether nuclear $\mathrm{Ca}^{2+}$ buffering could improve the effect of clinical doses of X-rays on human SCC growth. For that, we developed a refined in vitro daily fractioned irradiation model, based on head and neck radiotherapy protocol, to evaluate the role of the association therapy on cell proliferation. We found that nuclear $\mathrm{Ca}^{2+}$ buffering increased radiation efficacy, at least

*Corresponding author: M. Fátima Leite, Ph.D, Department of Physiology and Biophysics, Federal University of Minas Gerais, Av. Antônio Carlos 6627 Pampulha, Belo Horizonte, MG, Brazil 31270-901, Tel: (55+31)3409-2947; Fax (55+31)3409-2924; E-mail: leitemd@dedalus.lcc.ufmg.br

Received April 08, 2012; Accepted May 23, 2012; Published May 25, 2012

Citation: Andrade LM, Geraldo JM, Gonçalves OX, Leite MTT, Catarina AM, et al. (2012) Nucleoplasmic Calcium Buffering Sensitizes Human Squamous Cel Carcinoma to Anticancer Therapy. J Cancer Sci Ther 4: 131-139. doi:10.4172/19485956.1000127

Copyright: (c) 2012 Andrade LM, et al. This is an open-access article distributed under the terms of the Creative Commons Attribution License, which permits unrestricted use, distribution, and reproduction in any medium, provided the original author and source are credited. 
Citation: Andrade LM, Geraldo JM, Gonçalves OX, Leite MTT, Catarina AM, et al. (2012) Nucleoplasmic Calcium Buffering Sensitizes Human Squamous Cell Carcinoma to Anticancer Therapy. J Cancer Sci Ther 4: 131-139. doi:10.4172/1948-5956.1000127

in part, by preventing ADAM-17 over expression and consequently EGFR activation.

\section{Materials and Methods}

\section{Cell culture, human material and reagents}

We used skin human squamous epidermoid carcinoma (HSCC), A431cell line. SCC of skin is known to have a predilection for the head and neck region [13], and we used squamous cell carcinoma cell line because of its well-known radioresistance behavior [14-17]. A431 cell line was obtained from Rio de Janeiro Cell Bank-RJCB (Rio de Janeiro, Brazil), and primary cell culture of human gingival fibroblast was kindly donated by Dr. Melissa M. Guimarães from Federal University of Vales do Jequitinhonha and Mucurí, Brazil. Human materials used in this study were undertaken under Institutional Review Board approved protocol (RD OO3/09), after obtaining informed consent. Upon arrival, A431 cells were immediately expanded and frozen. These cells could be restarted every 3 months from a frozen vial of the same batch of cells. Cells were grown at $37^{\circ} \mathrm{C}$ with $5 \% \mathrm{CO}_{2}$ in RPMI- 1640 supplemented with 5\% FBS or DMEM containing $1 \mathrm{mM}$ sodium pyruvate, supplemented with $10 \%$ FBS, respectively, plus 50 units/ $\mathrm{mL}$ penicillin, and $50 \mathrm{~g} / \mathrm{mL}$ streptomycin, all from Gibco (Grand Island, NY). Horseradish peroxidase conjugated goatanti-rabbit IgG and TRI-reagent from Sigma Aldrich (St Louis, USA), polyclonal anti-rabbit ACE from Santa Cruz Biotechnology, (SantaCruz, USA), monoclonal anti-rabbit EGFR from Cell Signaling (Boston, USA), antiphospho-EGFR (Tyr1173), clone 9H2 from Millipore (Billerica, MA), First-Strand cDNA Synthesis Kitfrom Fermentas (Ontário, Canada), SYBR $^{\circ}$ Green PCR Master Mix and StepOnePlus ${ }^{\text {ix }}$ Real-Time PCR System from Applied Biosystems (Foster City, USA), Alexa-488 from Invitrogen (Maryland, USA). All other reagents were of the highest quality that was commercially available.

\section{Irradiation planning and dosimetry}

Acrylic platform, measuring $27 \times 25 \mathrm{~cm}$, was designed to maintain the cells correctly positioned during irradiation. The platform was positioned in the middle of the water bath and CT images were acquired using Sensation 64 Siemens (Malvern, USA). CAT 3D for WIN 32 software was used for radiotherapy planning. Isodose curves were determined using two vertical parallel opposed radiation fields. For dosimetry, the $25 \times 25 \mathrm{~cm}^{2}$ field sizes and Monitor Units (MU) linear accelerator setting were used. The phantom was scanned in depth along central ray and in cross plane direction of the radiation field. For details see supplementary material and methods.

\section{Radiotherapy procedures}

$\mathrm{X}$-rays beam from 4MV linear accelerator CLINAC 4X (Varian, USA) was used for these studies. The cells were irradiated using isocentric technique with the linear accelerator positioned at the base of the adhered cells. Two vertical parallel opposed fields were used. The Source-axis distance (SAD) was $80 \mathrm{~cm}$, the gantry angles were $180^{\circ}$ and $0^{\circ}$, and for a question of choice the Source-surface distance (SSD) were $684.9 \mathrm{~mm}$ and $653.5 \mathrm{~mm}$, respectively. The field size of 25 x $25 \mathrm{~cm}^{2}$ at the isocenter plane was the same for both fields. The cells were irradiated with fractioned daily doses of $2 \mathrm{~Gy}$ during five days. The geometrical arrangement described above was MU: 116 for the anterior field and 129 for the posterior field. To maintain the electronic equilibrium during X-rays irradiation, T25 tissue flasks were filled with supplemented RPMI. Room conditions were: $20^{\circ} \mathrm{C}$, relative air humidity of $42 \%$, and atmospheric pressure of $92.2 \mathrm{kPa}$. Assays were initiated $5 \mathrm{~h}$ after irradiation.

\section{In vitro irradiation geometrical arrangement}

Geometrical in vitro irradiation can be described mathematically as:

$$
M U=\frac{D}{2 F_{c a l} x T M R\left(d, r_{d}\right) x S_{c}\left(r_{c}\right) x S_{p}\left(r_{d}\right)} \times\left(\frac{S A D}{S C D}\right)^{2}
$$

where $M U$ is monitor units; $D$ is dose; $F_{\text {cal }}$ is calibration factor; TMR is tissue maximum ratio; ${ }_{d}$ is depth; $r_{d}$ is field width at depth ${ }_{d} S_{c}$ is collimator scatter; $r_{c}$ is field width defined by collimator jaws; $S_{p}$ is phantom scatter; $S A D$ is source axis distance and SCD is source chamber distance.

\section{Nuclear $\mathrm{Ca}^{2+}$ buffering}

To selectively buffer nuclear $\mathrm{Ca}^{2+}$, we used a vector containing the cDNA for the $\mathrm{IP}_{3}$ binding domain (residues 224-605) of the human type $\mathrm{IIP}_{3}$ receptor that was tagged with monomeric red fluorescent protein (mRFP) and the Nuclear Localization Signal (NLS), as described [18]. A type $\mathrm{V}$ recombinant adenovirus (200 MOI) containing the nuclear $\mathrm{IP}_{3}$ buffer vector was used to selectively deliver the $\mathrm{Ca}^{2+}$ buffer construct into the cells.

\section{Cell proliferation assay}

A431 cells and human gingival fibroblasts were directly counted as previously described [11].

\section{Clonogenic assay}

Clonogenic assay was performed as previously described [19] Briefly, after progressively cumulative dose and after each day of experimental conditions, $1.0 \times 10^{3}$ and $2.0 \times 10^{3}$ cells were seeded onto 6 well tissue culture plates, containing $5 \mathrm{~mL}$ culture medium. The cells were incubated to 15 days and then dyed using a mixture of $6 \%$ of glutaraldehyde (Merck, Darmstadt, Germany) and $0.5 \%$ crystal violet (Vetec, Duque de Caxias, Brazil) for $12 \mathrm{~h}$. Mixture was removed and colonies formation was counted.

\section{Flow cytometry assay}

Cell cycle phase was performed as previously described [20]. Briefly, A431 cells were stained with HFS $0.5 \%$ solution $(0.5 \%$ sodium citrate $\mathrm{w} / \mathrm{v}$, from Merck, $0.5 \mathrm{mg} / \mathrm{mL}$ propidium iodide (PI), from Sigma and $0.5 \%$ Triton X-100 v/v, from USB, Cleveland, USA). DNA content was determined using a FACSCalibur (BD Biosciences, USA). Data were analyzed by BD Cell Quest software (USA).

\section{Immunoblotting}

Standard methods were used for immunoblots [12]. Briefly, 40 $\mu \mathrm{g}$ of whole cell protein was subject to sodium-dodecyl-sulphate polyacrylamide gel electrophoresis (SDS-PAGE) in $8 \%$ Tris- $\mathrm{HCl}$ gels, as indicated. Proteins were transferred to PVDF membranes followed by antibody labeling. Primary antibodies used to ADAM-17 and EGF Receptor were: polyclonal anti-rabbit TACE (1:1000); monoclonal antirabbit EGF Receptor (1:1000). Antibodies were incubated overnight at $4^{\circ} \mathrm{C}$. After washing, blots were incubated with a horseradish peroxidase conjugated goat-anti-rabbit IgG secondary antibody (1:5000) at room temperature for $1 \mathrm{~h}$. Westerns were developed with ECL-plus reagent and films were scanned with a GS-700 imaging densitometer (BioRad, USA). The analyses of these images were performed using ImageJ software (NIH, Bethesda, MD).

\section{Real-time PCR}

Real-time PCR was performed as previously described [12,21]. Total 
RNA was obtained using the TRIzol reagent and $2 \mu \mathrm{g}$ of total RNA were used for retro-transcription using the First-Strand cDNA Synthesis Kit. Real-time quantitative PCR for ADAM-17 was performed using SYBR ${ }^{\circ}$ Green PCR Master Mix, and the dissociation curves were performed to confirm the specificity of products.

The ADAM-17 forward primer was 5'-GGACCCCTTCCCAAATAGCA $-3^{\prime}$ and reverse primer was 5'-ATGGTCCGTGAGATCCTCAAA -3'. The threshold cycles (CT) values of target genes were normalized relative to glyceraldehydes3-phospate dehydrogenase gene, and relative expression ratios were calculated by the $2-\Delta \Delta$ Ct method. EGFR forward primer was 5'-CTTTCGATACCCAGGACCAAG-3' and reverse primer was 5'-CAACTTCCCAAAATGTGCCC-3'. Negative controls were treated with water and total RNA was non-reverse transcribed. DNA templates were amplified by real time PCR on the StepOnePlus ${ }^{\text {Tm }}$ Real-Time PCR System using the $\mathrm{SYBR}^{\oplus}$ green method; $\beta$-actin was used as an internal control to normalize variations in DNA concentrations. Experiments were performed in triplicate for each data point. After amplification, electrophoresis of $10 \mu \mathrm{L}$ reaction mixture on a $2 \%$ NuSive:agarose gel (3:1) (FMC product, Rockland, ME) was visualized under UV illumination after staining with ethidium bromide.

\section{Immunofluorescence}

These experiments were performed as described [12,18]. Images were obtained using a Zeiss LSM 510 confocal microscope (Thornwood, NY) with excitation at $488 \mathrm{~nm}$ and observation at 505-550 nm.

\section{Statistical analysis}

The results are expressed as means and SEM. Prism (Graph Pad Prism software, San Diego, CA) was used. Statistical significance was tested with one-way analysis of variance and the $t$ test or KruskallWallis and Mann-Whitney test depending on the parametric or nonparametric data nature. In all cases, the $\mathrm{p}<0.05$ was considered to indicate statistical significance.

\section{Results}

\section{Water phantom improves dose distribution across cells using fractionated schedule}

Radiotherapy is based on traditional radiobiological models in which cells hit by radiation, either directly or indirectly, present increased probability of death [22]. Despite large improvements in cancer therapy, a better understanding of cell biology effects induced by radiation still needs further investigation. Here, we developed an in vitro irradiation model to monolayer cells, based on head and neck treatment parameters, using tissue flasks fulfilled with medium, and immersed into water phantom positioned by an acrylic platform (Supplementary Figure 1A-1C). Reproducibility in planning target volume during radiotherapy is one of the most important parameters to treatment success [23]. Therefore, the platform was constructed to maintain tissue flasks in a fixed position, ensuring target cells reproducibility during irradiation and allowing a better X-rays absorption and scattering.

Computed Tomography localization and virtual dose simulation are tools used to provide more accurate tumor target, in order to reduce geographical misses and treatment-related toxicity [24]. To ensure that in our experimental setup the SCC cell line would be able to receive the total prescribed dose, we performed radiotherapy planning of the cells, similarly to what is done for in vivo studies (Figure 1A-1B). The color lines represent the isodoses curves and the percentage of absorbed dose. The radiotherapy planning shows that inside irradiation field, all cells receive the same percentage of doses. We also observed uniform distribution of absorbed dose across tissue flasks in parallel opposed fields including lateral flasks borders (Supplementary Movie 1). Since radiotherapy demands accurate dose determination for delivery of highly dose uniformity we evaluated the dose-volume histogram as well as real dosimetry measurements, using ionization chambers (Figure 1C-1D). We found that independent of the flasks position inside irradiation field, all tissue flasks can receive $100 \pm 2 \%$ of the total calculated dose (Figure 1C). Moreover, depth dose measurements, using our setup, showed that there is no difference in the dose delivered to the cells compared to the computational dosimetry (Figure 1D). It also showed that depth dose curves for parallel opposed field normalized to midpoint value were similar to what has been proposed for $4 \mathrm{MV}$ energy beam [25]. While a correctly delivery of X-rays has many potential benefits, a poor delivery may lead to the opposite outcome [26]. Therefore, the position accuracy of the tissue culture flasks was verified using oncologic film (Supplementary Figure 2).

Several methods are available for in vitro irradiation of cell monolayers [22]; however, non-uniformity of doses along field profile hampers cell biology conclusions. Our in vitro radiobiology model provides uniform irradiation to monolayer cells minimizing uncertainties. Moreover, Monitor Units (MU) relates the dose at any point on the central ray of the treatment beam as a function of beam parameters such as source axis distance (SAD), field size (rd) and depth $d$ of the interest [27]. We also tested a MU equation that permits the cells to be treated based on radiotherapy equipment parameters, applying it in diverse radiotherapy machines (Supplementary Figure 3A-3B). In contrast with conventional models for in vitro irradiation that uses tissue flasks irradiated under air column, dosimetry measurements in our proposed model, confirmed dose uniformity across cells (Figure $1 \mathrm{E}-1 \mathrm{G})$. Using our irradiation setup, we then investigated cell cycle profile of A431 cells, under the conventional in vitro irradiation protocol of $10 \mathrm{~Gy}$ single $\mathrm{X}$-rays dose $\left(\mathrm{XR}_{\mathrm{Sd}} 10 \mathrm{~Gy}\right)$, in comparison with $10 \mathrm{~Gy}$ cumulative dose, fractioned schedule of $2 \mathrm{~Gy}$ for up to 5 days $\left(\mathrm{XR}_{\mathrm{Cd}} 10 \mathrm{~Gy}\right)$, (Figure $\left.2 \mathrm{~A}-2 \mathrm{~B}\right)$. In cells that receivedXR $10 \mathrm{~Gy}$, there was a significant $(\mathrm{p}<0.001)$ decrease in $\mathrm{G}_{0} / \mathrm{G}_{1}$ phase $(34.8 \pm 2.5 \%)$, but an increase in the percentage of cells in the $\operatorname{SubG}_{1}(19.4 \pm 2 \%), \mathrm{G}_{2} / \mathrm{M}$ $(23.9 \pm 1.5 \%)$, and $\mathrm{S}(21.5 \pm 2.3 \%)$ phases relative to control. Under $\mathrm{XR}_{\mathrm{Cd}} 10 \mathrm{~Gy}$, compared to control, there was no significant change in the $\mathrm{SubG}_{1}$, an indicative of radioresistance. However, there was a decrease in the $\mathrm{G}_{0} / \mathrm{G}_{1}$ phase $(57 \pm 1.5 \%)$ and increase in the $\mathrm{G}_{2} / \mathrm{M}$ phase $(29.6$ $\pm 1.3 \%)$, relative to control, respectively $(71.7 \pm 2.8 \%$ and $13.7 \pm 2 \%$, $\mathrm{p}<0.001)$.Clearly, cell death $\left(\right.$ SubG $\left._{1}\right)$ was more pronounced $(\mathrm{p}<0.01)$ in $\mathrm{XR}_{\mathrm{Sd}} 10 \mathrm{~Gy}(19.4 \% \pm 3.6 \%)$ compared to $\mathrm{XR}_{\mathrm{Cd}} 10 \mathrm{~Gy}(4.3 \% \pm 2 \%)$, suggesting an intrinsic adaptive response against cell death induced by fractionated X-rays injury. These findings show that using single or cumulative irradiation protocol drives cells towards distinct cell cycle profile. The observed differences infractioned schedule cannot be attributed to bystander effect, because all cells received an uniform irradiation dose.

Taking together, our data demonstrated that not only the irradiation setup but also the irradiation protocol, represented by single versus cumulative dose, are important patterns to consider when studying cell biology events that happen under radiotherapy treatment.

\section{Buffering nuclear $\mathrm{Ca}^{2+}$ decreases cell proliferation and alter EGFR activation}

Although radiotherapy is a standard protocol for SCC therapy, in many cases, radioresistance and even enhanced proliferation of 
Citation: Andrade LM, Geraldo JM, Gonçalves OX, Leite MTT, Catarina AM, et al. (2012) Nucleoplasmic Calcium Buffering Sensitizes Human Squamous Cell Carcinoma to Anticancer Therapy. J Cancer Sci Ther 4: 131-139. doi:10.4172/1948-5956.1000127

surviving tumor cell fractions occurs. There is, therefore, an urgent need to exploit new targets, which in combination with X-rays could improve therapeutic options for human SCC. An important molecular target to address is the intracellular $\mathrm{Ca}^{2+}$, since it plays a vital role in cell proliferation [28]. In fact, it was recently demonstrated that nuclear, rather than cytosolic $\mathrm{Ca}^{2+}$ regulates the growth of liver tumors [11]. We now investigated whether nuclear $\mathrm{Ca}^{2+}\left(\mathrm{Ca}^{2+}{ }_{n}\right)$ is involved in the proliferation rate of human SCC and whether it affects the cell sensitivity to irradiation. For that, A431 cells were infected with a construct that has the ligand binding site domain (residues 224-605) of the intracellular $\mathrm{Ca}^{2+}$ channel, type I IP ${ }_{3} \mathrm{R}$. This segment of $\mathrm{IP}_{3} \mathrm{R} 1$ specifically binds to $\mathrm{IP}_{3}$ with sufficient affinity to compete for the binding to the native receptor [29]. The construct is targeted to the nucleus using a nuclear localization signal and it contains mRFP to verify intracellular localization [18]. The efficiency and selectivity of the vector to buffer $\mathrm{Ca}^{2+}$ in the nucleus were previously demonstrated $[18,30]$. In order to maximize the expression of the $\mathrm{Ca}^{2+}{ }_{n}$ to a higher number of cells we now use an adenovirus delivery system (Figure 3A). We measured cell proliferation directly by cell counting and found that $\mathrm{Ca}^{2+}{ }_{\mathrm{n}}$ buffering significantly decrease A431proliferation rate to approximately $50 \%$ of controls (Figure 3B). On the other hand, $\mathrm{Ca}^{2+}{ }_{n}$ buffering did not affect proliferation of normal human gingival fibroblast (Figure 3C). It was previously demonstrated that $\mathrm{Ca}^{2+}{ }_{\mathrm{n}}$ buffering increased the fraction of tumor liver cells in $\mathrm{G}_{2} / \mathrm{M}$ transition phase acting during early mitosis to decrease cell proliferation [11]. We then used flow cytometry to analyze A431 cell cycle phases. The cells were submitted to $\mathrm{XR}_{\mathrm{Cd}} 10 \mathrm{~Gy}$
A

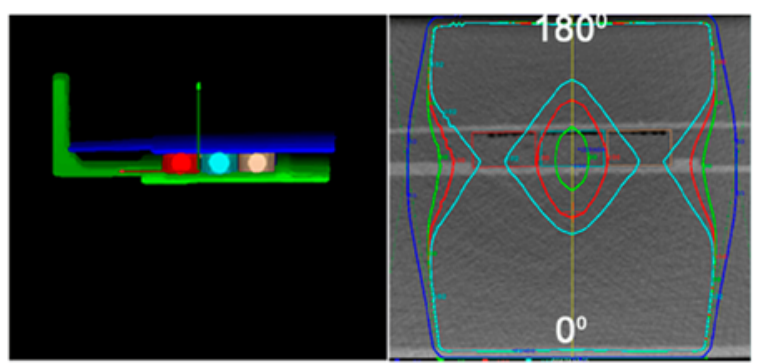

B
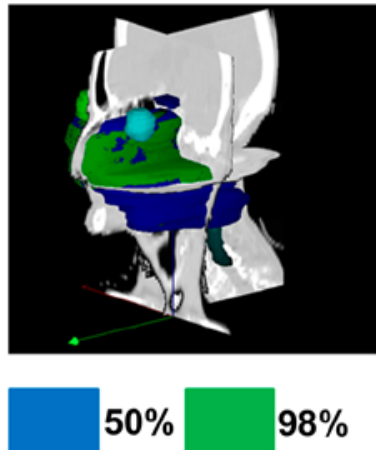

$\mathbf{E}$

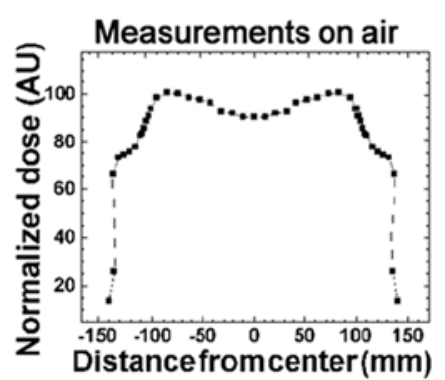

C

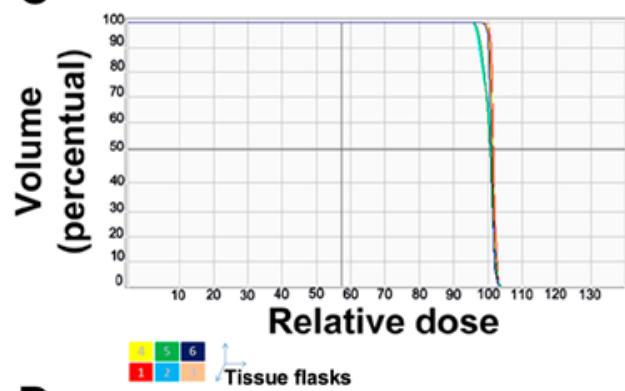

D

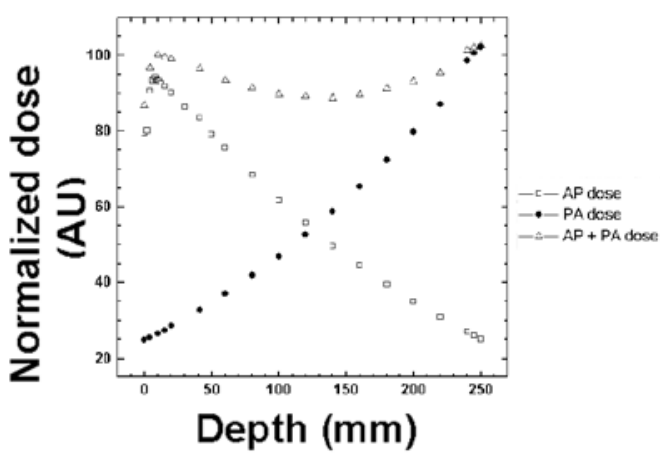

G
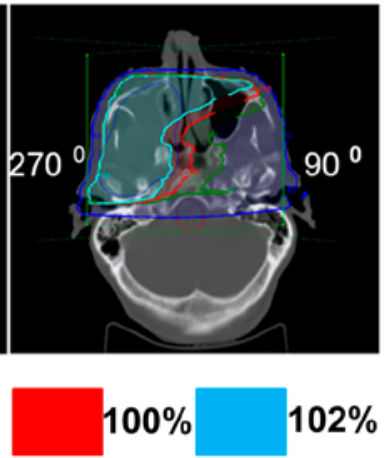

$\mathbf{F}$

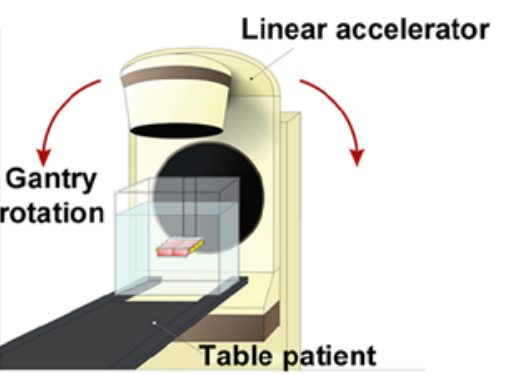

Measurements on water

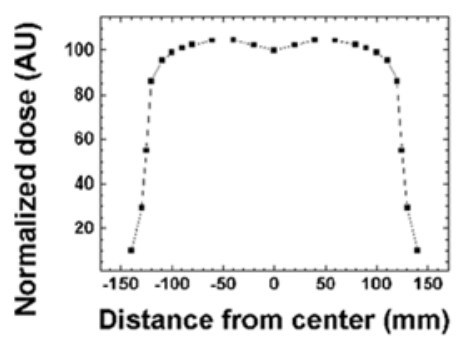

Figure 1: Irradiation planning and X-rays measurements. A. Radiotherapy planning to A431 cells in tissue flasks based on computer tomography images. Right panel shows isodoses curves for vertical parallel opposed fields, as well as the percentage of doses absorbed by the A431 cells. B. Radiotherapy planning of SCC maxillary sinus. Isodoses curves for lateral parallel opposed fields and the percentage of absorbed doses are represented. C. Dose-volume histograms calculated by CAT3D for win.32. D. Real dosimetry measurements for the in vitro irradiation model using ionization chamber. The depth doses curves for parallel opposed fields was measured and normalized to isocenter. E. Dose profile of conventional in vitro irradiation model measured by ionization chamber in air. Data show non-uniformity dose along the field profile. F. Schematic diagram for the in vitro irradiation model using a 4MV linear accelerator and acrylic platform positioned inside phantom filled with water. G. Dose profile of the proposed in vitro irradiation model measured by ionization chamber immersed in water phantom. Data demonstrate uniformity dose distribution along the irradiation field. 
or $\mathrm{Ca}^{2+}{ }_{\mathrm{n}}$ buffering single therapies, as well as to association therapy, and compared to untreated cells. In populations that received either $\mathrm{X}$-rays irradiation or expressed $\mathrm{Ca}^{2+}{ }_{n}$ buffer, there was a significant $(\mathrm{p}<0.01)$ increase in the percentage of cells in the $\mathrm{G}_{2} / \mathrm{M}$ phase $(29.6$ $\pm 2.7 \%$, and $29.9 \pm 3.4 \%$, respectively), but a reduction in the $\mathrm{G}_{0} / \mathrm{G}_{1}$ phase $(57.1 \pm 3.6 \%$, and $55.4 \pm 4.5 \%$,respectively), with no change in the percentage of cells in SubG 1 phase $(4.3 \pm 2.4 \%$, and $5.1 \pm 1.7 \%$, respectively), relative to control $(3.0 \pm 1.5 \%, \mathrm{p}>0.05)$ (Figure $3 \mathrm{D})$. However, association therapy increased even more the percentage of cells in $\mathrm{G}_{2} / \mathrm{M}$ phase $(35.7 \pm 2.0 \%, \mathrm{p}<0.001)$, and caused a small, but

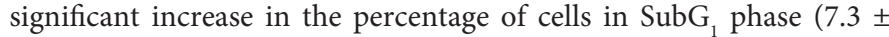
$2.5 \%, \mathrm{p}<0.05$ ), compared to control (Figure $3 \mathrm{D}$ ). We then investigated whether $\mathrm{Ca}^{2+}$ buffering, besides affecting cell cycle profile, would be able to drive tumor cells to a more susceptible radiation-induced DNA damage. Therefore, we evaluated nuclear and mitochondrial DNA lesions, in cells that were exposed to association therapy in comparison with each treatment alone and untreated cells (Supplementary Figure $4 \mathrm{~A}-4 \mathrm{~B})$. We observed no difference in nuclear DNA lesions among the experimental conditions. At earlier time point of the association therapy we observed a small increase in mitochondrial DNA lesions (1.4 \pm $0.2 \%$ vs $0.1 \pm 0.002 \%$ in control cells, $\mathrm{p}<0.05$ ), an effect not observed at later time interval. Additionally, we found no effect on mitochondrial activity under any experimental condition (Supplementary Figure 4C). Together, these findings show that $\mathrm{Ca}^{2+}{ }_{n}$ buffering decreases the rate of human SCC proliferation, and when associated with cumulative $\mathrm{X}$-rays irradiation it arrests the cells in $\mathrm{G}_{2} / \mathrm{M}$ transition to a higher extent compared to each treatment alone, without affecting nuclear or mitochondrial DNA lesions. In fact, the observed absence of DNA damage correlates with the well-known ability of SCC to repair DNA lesions induced by irradiation [31].

Aggressive tumor behavior and increased tumor resistance to cytotoxic agents, such as X-rays, is known to present dysregulated EGFR signaling cascade $[4,7,32]$. Moreover, X-rays can increase the expression of members of metalloproteinase (ADAM) family that are thought to mediate the shedding of EGFR ligands, a critical step

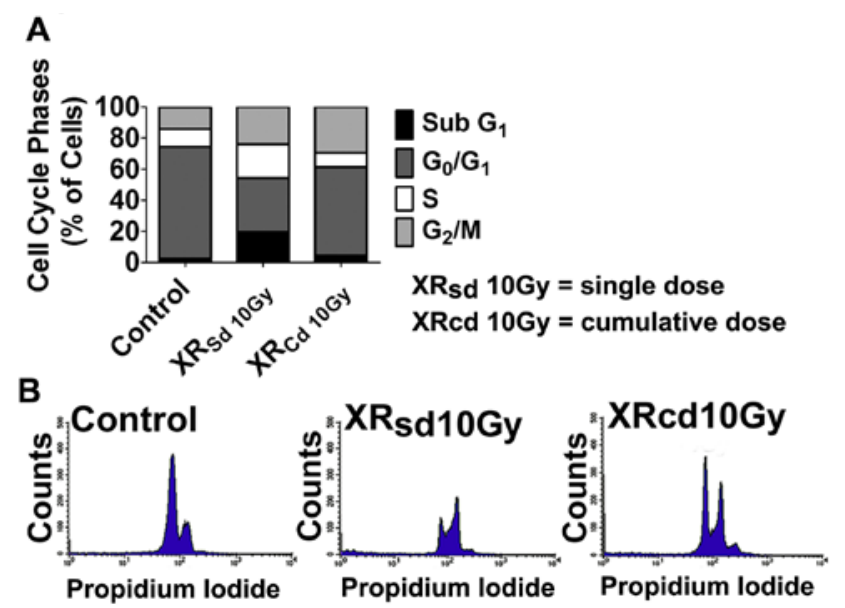

Figure 2: Cell cycle kinetics after single or cumulative $X$-rays irradiation. A431 cells receiving $10 G y$ X-rays dose using either the conventional single dose model $\left(X_{\mathrm{S}} 10 \mathrm{~Gy}\right)$ or cumulative 10Gy irradiation by fractionated doses of $2 \mathrm{~Gy}$ for 5 days (XR 10Gy). A. Percentage of cells in each phase of the cell cycle. Cell death was higher after single dose when compared to control and after cumulative dose ( $p<0.001$, Kruskall-Wallis test, $N=3$ ). B. Representative FACS cell cycle profile of A431 control cells and A431 cells irradiated with single or cumulative dose.

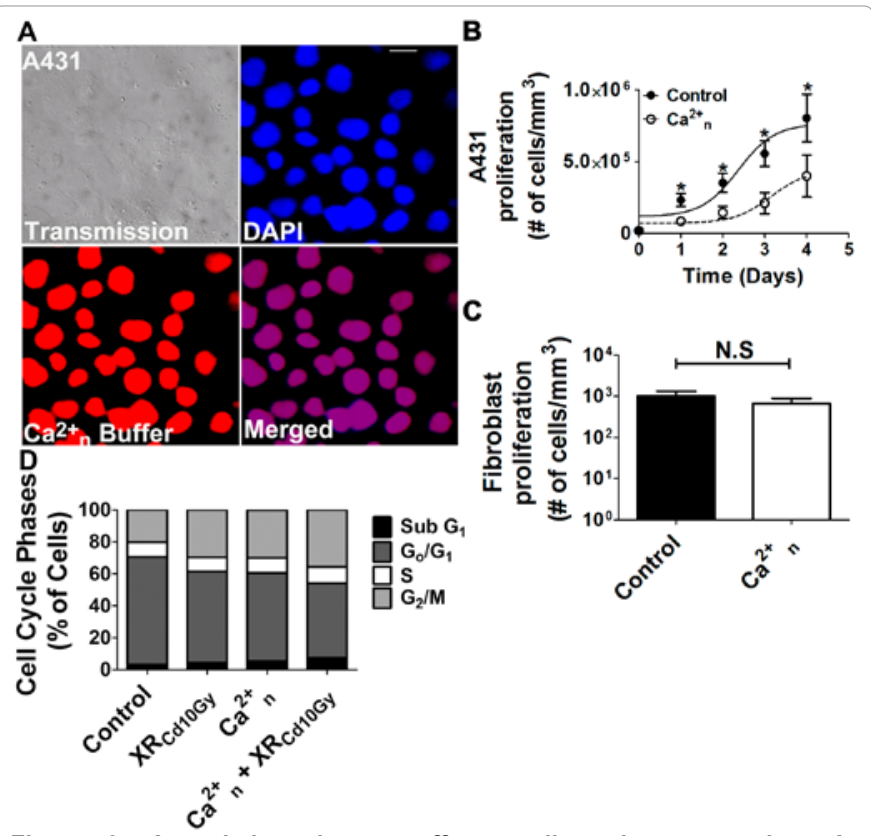

Figure 3: Association therapy affects cell cycle progression. A. Representative image of adenovirus infection on A431 cells. Superior panels show transmission image of A431 cells and nuclei stained with DAPI (blue). Left inferior panel shows expression of the $\mathrm{Ca}^{2+}$ buffering cassette (red). Merged image on right inferior panel confirms expression of nuclear $\mathrm{Ca}^{2+}$ buffering in $100 \%$ of the cells. B. Cell growth curve of A431 cells 24, 48, 72 and 96 $\mathrm{h}$ in control conditions and after infection with a type $\mathrm{V}$ adenovirus construct that buffers $\mathrm{Ca}^{2+}{ }_{n}$ signaling. Proliferation is decreased upon $\mathrm{Ca}^{2+}{ }_{n}$ buffering compared to control, $(p<0.0001, t$ test was used for each day of experiment, and one-way analysis of variance, Bartlett's test for equal variances, for all groups, $N=3$ ). C. Cell proliferation of human gingival fibroblast at $96 \mathrm{~h}$ under control or $\mathrm{Ca}^{2+}$ buffering condition. There were no significant changes in cell proliferation between control and fibroblasts that had $\mathrm{Ca}^{2+}$ buffered $(\mathrm{N}=3)$. $\mathrm{D}$. Cell cycle phase analysis of A431 cells under control conditions, XR 10Gy, $\mathrm{Ca}^{2+} \mathrm{n}$, and after $\mathrm{Ca}^{2+}{ }_{\mathrm{n}}+\mathrm{XR}_{\mathrm{Cd}} 10 \mathrm{~Gy}$ conditions. Under association therapy the number of cells in $\mathrm{G}_{2} / \mathrm{M}$ phase increased compared to control. The data are expressed as mean \pm SEM of triplicate measurements and are representative of $\mathrm{N}=3$ experiments $(\mathrm{p}<0.05$, one-way analysis of variance). for the production of soluble functional agonists for growth factor receptors [33]. We then investigated whether association of $\mathrm{Ca}^{2+}{ }_{\mathrm{n}}$ buffering would affect expression of ADAM-17 and EGFR induced by $\mathrm{XR}_{\mathrm{Cd}} 10 \mathrm{~Gy}$, at RNA and protein levels (Figure 4). Real-time PCR showed, as expected, that $\mathrm{X}$-rays irradiation increased expression of ADAM-17 and EGFR to $3.0 \pm 0.5 \mathrm{AU}$, and to $3.4 \pm 0.3 \mathrm{AU}$, respectively, compared to $1.0 \pm 0.3 \mathrm{AU}$ and $1.0 \pm 0.4 \mathrm{AU}$ in control conditions (Figure $\left.4 \mathrm{~A}-4 \mathrm{~B},{ }^{* *} \mathrm{p}<0.01\right) . \mathrm{Ca}^{2+}{ }_{\mathrm{n}}$ buffering did not alter the expression levels of ADAM-17 but reduced expression of EGFR to $0.5 \pm 0.2 \mathrm{AU}$, below the expression level of untreated cells $\left.{ }^{* * *} \mathrm{p}<0.001\right)$. Under association therapy the expression of ADAM-17 and EGFR were $1.1 \pm 0.5 \mathrm{AU}$, or $1.8 \pm 0.6 \mathrm{AU}$, compared to control $\left({ }^{*} \mathrm{p}<0.05\right)$. These results were also investigated at protein level (Figure $4 \mathrm{C}-4 \mathrm{~F}$ ). We found that the expression of ADAM-17 increased to $0.69 \pm 0.01 \mathrm{AU}$ in cells submitted to $\mathrm{XR}_{\mathrm{Cd}} 10 \mathrm{~Gy}$ and reduced to $0.45 \pm 0.1 \mathrm{AU}$, or to $0.50 \pm 0.07 \mathrm{AU}$ in cells under $\mathrm{Ca}^{2+}{ }_{\mathrm{n}}$ buffering or association therapy, respectively $(\mathrm{p}<0.05)$. On the other hand, we found that X-rays irradiation did not alter EGFR protein expression level, but the buffering of $\mathrm{Ca}^{2+}{ }_{\mathrm{n}}$ decreased EGFR expression below control level, even under $\mathrm{XR}_{\mathrm{Cd}} 10 \mathrm{~Gy}(0.23 \pm 0.01 \mathrm{AU}$ in $\mathrm{Ca}^{2+}$ buffered cells vs $0.42 \pm 0.09 \mathrm{AU}$ in association therapy vs 0.45 $\pm 0.19 \mathrm{AU}$ in control cells, ${ }^{*} \mathrm{p}<0.05{ }^{* *} \mathrm{p}<0.01$ ), (Figure $4 \mathrm{C}-4 \mathrm{~F}$ ). The observed changes in the expression level of ADAM17 and EGFR are 
A

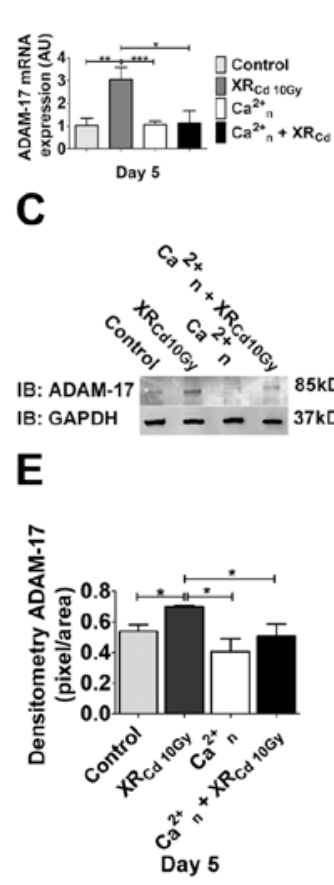

B

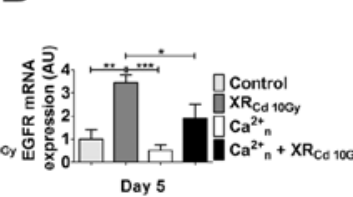

D

\section{G}

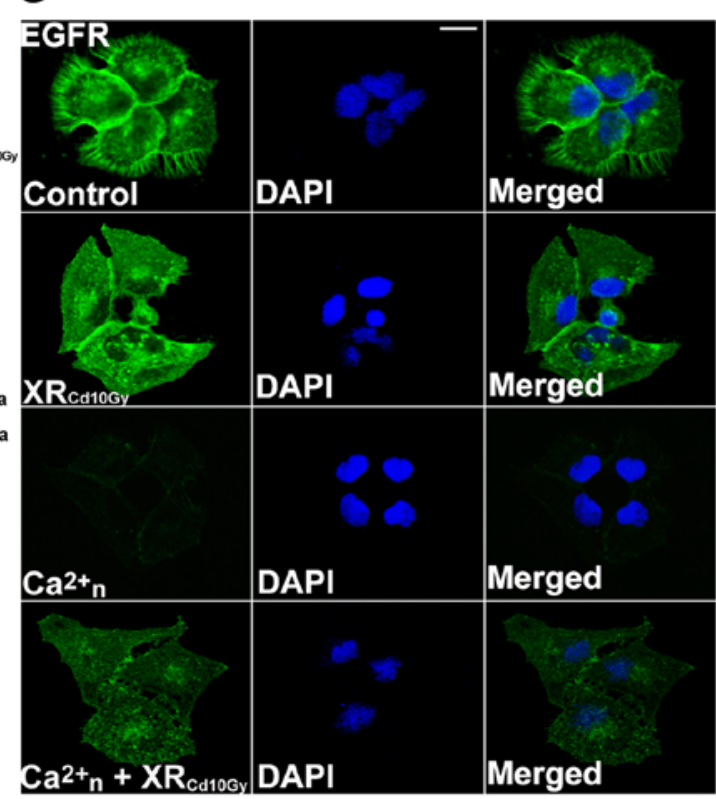

$\mathrm{H}$
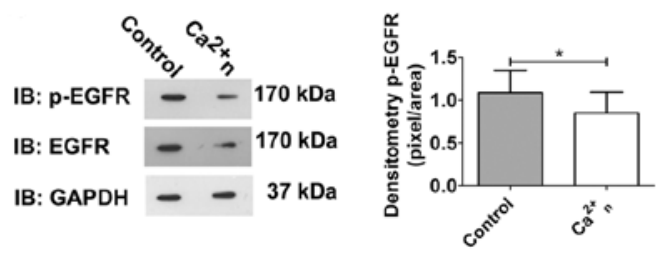

Figure 4: Nuclear $\mathrm{Ca}^{2+}$ buffering prevents ADAM-17 and EGFR overexpression levels induced by cumulative $\mathrm{X}$-rays irradiation. A. Real-Time PCR demonstrated that XR $10 \mathrm{~Gy}$ increased mRNA expression of the metalloproteinase ADAM-17 $\left({ }^{* *} \mathrm{p}<0.01\right.$, using $t$ test). Ca ${ }^{2+}$ buffering (Ca ${ }^{2+}$ ) did not affect ADAM-17 expression levels, but prevented the increase ofADAM-17 mRNA expression induced by $X R_{C d} 10 G y$. B. EGFR mRNA expression increased compared to control, after $X_{C d} 10 G y\left({ }^{* *} p<0.01\right.$, using $t$ test). Ca ${ }^{2+}$ buffering decreased EGFR mRNA expression levels induced by $X R_{C d} 10 G y\left({ }^{* * *} p<0.001\right.$, using $t$ test). C-D. Western blotting to validate the expression patterns of ADAM-17 and its downstream effector, EGFR. E-F. Densitometric analyzes of ADAM-17 and EGFR proteins expression. Data show reduction in expression of both proteins under $\mathrm{Ca}^{2+}{ }_{n}$ buffering condition, even upon $\mathrm{XR}{ }_{\mathrm{Cd}} 10 \mathrm{~Gy},\left({ }^{*} \mathrm{p}<0.05\right.$, ${ }^{* *} \mathrm{p}<0.01$, analyzed using $t$ test), in $\mathrm{N}=3$. $\mathbf{G}$. Imunofluorescence images show that $X_{C d} 10 G y$ induces translocation of EGFR from plasma membrane to the cell interior. $H$. Western blot of $p$-EGFR shows reduction of phosphorylated EGFR expression under $\mathrm{Ca}^{2+}{ }_{n}$ buffering $\left({ }^{*} \mathrm{p}<0.05\right.$, using $t$ test).

specific, since the internal control (GADPH) used in each situation was unaffected under similar nuclear $\mathrm{Ca}^{2+}$ buffering condition.

It is known that exposure to irradiation triggers internalization of EGFR from the plasma membrane to cell interior due to EGFR activation [34]. Therefore, we investigated whether $\mathrm{Ca}^{2+}{ }_{n}$ buffering would alter EGFR internalization induced by $\mathrm{XR}_{\mathrm{Cd}} 10 \mathrm{~Gy}$. For that, we performed immunofluorescence, and found that $\mathrm{Ca}^{2+}$ buffering not only reduced EGFR expression level, but also reduced EGFR internalization, upon $\mathrm{XR}_{\mathrm{Cd}} 10 \mathrm{~Gy}$ (Figure 4G). Additionally, phosphorylation levels of EGFR were reduced following $\mathrm{Ca}^{2+}{ }_{\mathrm{n}}$ buffering, indicating less activation of the receptor (Figure $4 \mathrm{H}$ ). Together, these data show that $\mathrm{XR}_{\mathrm{Cd}} 10 \mathrm{~Gy}$ triggers prosurvival mechanisms in A431 cells, which could be regarded as an adaptive response to radiation damage, and be associated with radioresistance. $\mathrm{Ca}^{2+}$ buffering were shown to render these tumor cells more susceptible to radiation, by preventing ADAM-17 over expression and consequently EGFR activation.

Association therapy decreases cell survival fractions and allows reducing $\mathrm{X}$-rays dose

Activation of EGFR signaling by radiation is known to be related with increased cellular proliferation between radiation fractions, what may accelerate repopulation of tumor cell clonogens during treatment [31]. Rapid repopulation of tumor cells can lead to an earlier appearance of post-irradiation recurrences, and can therefore reduce the probability of tumor cure by radiotherapy. We then investigated, by clonogenic assay, whether $\mathrm{Ca}^{2+}{ }_{n}$ buffering would decrease or delay postirradiation proliferation of human SCC (Figure 5). For that, A431 cells were exposed to $\mathrm{Ca}^{2+}{ }_{n}$ buffering in association with $\mathrm{XR}_{\mathrm{Cd}} 10 \mathrm{G}$, followed by an in vitro cell clonogenic assay, performed 15 days after the end of the irradiation protocol. We observed that $\mathrm{XR}_{\mathrm{Cd}} 10 \mathrm{~Gy}$ decreased colony formation by $36 \pm 2.5 \%$ (54 \pm 11 colonies), while $\mathrm{Ca}^{2+}{ }_{n}$ buffering decreased colony formation by $28 \pm 2 \%$ ( $41 \pm 3$ colonies) compared to $148 \pm 14$ colonies in control ( $\left.{ }^{* *} \mathrm{p}<0.001\right)$, (Figure 5A-5B). Association therapy almost completely abolished colony formation. We found a decrease in colony formation by $91 \pm 0.4 \%$ ( $9 \pm 2$ colonies) compared to control $\left({ }^{* *} \mathrm{p}<0.0001\right)$. The radiation enhancement ratio of colony formation between X-rays treatment alone and X-rays associated with nuclear $\mathrm{Ca}^{2+}$ buffering strategy was 6 . These data indicates that repopulation of cells is significantly reduced under association therapy.

Intensification of radiotherapy for locally advanced SCC, by use of altered fractionation schedules or concomitant chemotherapy, has resulted in substantially improved loco regional control and survival. 


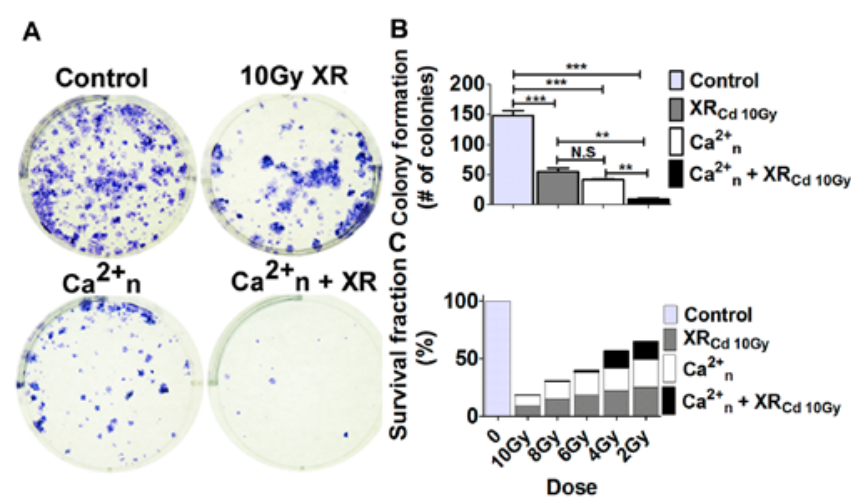

Figure 5: Association therapy decreases survival fraction and allows reducing irradiation dose. A-B. Clonogenic assay performed in 6 well plates cultured up to 15 days after $\mathrm{XR}_{\mathrm{Cd}} 10 \mathrm{~Gy}, \mathrm{Ca}^{2+}{ }_{\mathrm{n}}$ and association therapy condition $\left(\mathrm{Ca}^{2+}{ }_{n}+\mathrm{XR}_{\mathrm{Cd}} 10 \mathrm{~Gy}\right)$. Representative images show a decrease of colony formation under association therapy, $\left({ }^{* * *} \mathrm{p}<0.0001, t\right.$ test $), \mathrm{N}=3$. C. Association therapy not only decreased the percentage of A431 cell survival fraction, but also allowed reducing irradiation by approximately half of the cumulative dose $(\mathrm{N}=3$ individual experiments).

However, these improvements have come at the cost of increased acute, and late, toxic effects. For instance, in case of head and neck radiotherapy, dysphagia and xerostomia have a negative impact on quality of life $[35,36]$. Then, we investigated whether the association treatment modality would allow reducing the X-rays dose instead. For that, we evaluated the percentage of survival fraction in cells that received progressively less cumulative irradiation doses, under association with $\mathrm{Ca}^{2+}{ }_{n}$ buffering treatment. We found that decreasing cumulative irradiation dose to 6Gy in association with $\mathrm{Ca}^{2+}{ }_{\mathrm{n}}$ buffering treatment, maintained the survival fraction to values similar to what was observed for 10Gy (Figure 5C). These results show that association therapy not only reduced the percentage of survival cells, but also allowed reducing the X-rays cumulative dose to approximately half of the total dose.

Collectively, we now show that $\mathrm{Ca}^{2+}{ }_{n}$ buffering reduces A431 cell proliferation and radiosensitizes these cells to fractionated X-rays irradiation, at least in part through a mechanism that involves reducing expression of ADAM-17 and EGFR activation. Combining $\mathrm{Ca}^{2+}$ buffering with $\mathrm{XR}_{\mathrm{Cd}} 10 \mathrm{~Gy}$ also decreases survival fraction percentage of A431cells and allows reducing the cumulative radiation dose. Therefore, $\mathrm{Ca}^{2+}{ }_{\mathrm{n}}$ buffering may have a therapeutic potential for the treatment of SSC.

\section{Discussion}

It is well established that increases in $\mathrm{Ca}^{2+}$ signals occur in the cytoplasm and in the nucleus. Initial studies suggested that nucleoplasmic $\mathrm{Ca}^{2+}$ passively follow changes in cytoplasmic $\mathrm{Ca}^{2+}[37-$ 40]. However, additional studies demonstrated that intranuclear $\mathrm{IP}_{3}$ can increase $\mathrm{Ca}^{2+}$ directly within the nucleus, both in isolated nuclei [41-43], and in nuclei within intact cells $[44,45]$. It was also demonstrated that the nucleus contains $\mathrm{Ca}^{2+}$ stores including a nucleoplasmic reticulum [44], plus $\mathrm{PIP}_{2}$ [46], PLC [47], and $\mathrm{IP}_{3}$ receptors [48-52], collectively showing that the nucleus has the machinery needed to locally increase $\mathrm{Ca}^{2+}$, independently from the cytoplasmic $\mathrm{Ca}^{2+}$ signals. Additionally, there is evidence that $\mathrm{Ca}^{2+}{ }_{n}$ signals result from PIP hydrolysis and $\mathrm{IP}_{3}$ formation directly within the nucleus $[18,30]$. It has been long recognized that $\mathrm{Ca}^{2+}$ signals exerts an important role throughout the mammalian cell cycle and is especially important during early $G_{1}$, at
$\mathrm{G}_{1} / \mathrm{S}$ and $\mathrm{G}_{2} / \mathrm{M}$ transitions, with the first $\mathrm{Ca}^{2+}$ transient occurring just prior to entry into mitosis and the second one occurring during the metaphase-anaphase transition [53]. However, more recent findings demonstrated that nucleoplasmic, rather than cytosolic $\mathrm{Ca}^{2+}$ is essential for cancer cell proliferation, regulating cell cycle progression through early prophase [11]. This finding was confirmed in in vivo study, showing that liver tumors implanted in nude mice grew much more slowly when expressing a $\mathrm{Ca}^{2+}$ chelating protein, parvalbumin, in tumor cells nuclei, but not in the cytosol [11]. We now found that $\mathrm{Ca}^{2+}$ is also important in regulating SCC proliferation rate, an effect that was not observed in normal human gingival fibroblast, suggesting higher selectivity of $\mathrm{Ca}^{2+}{ }_{n}$ towards controlling cancer cells growth. Our results are in agreement with previous data that demonstrated that although $\mathrm{Ca}^{2+}$ regulates the growth of liver cancer cell line [11], hepatocyte proliferation during liver regeneration is regulated by cytosolic $\mathrm{Ca}^{2+}$ instead [54].

Further studies are needed to determine the mechanistic basis for differential sensitivity of normal versus cancer cell proliferation to $\mathrm{Ca}^{2+}{ }_{n}$. Nonetheless, one benefit of these findings altogether is that buffering $\mathrm{Ca}^{2+}{ }_{n}$ could be a strategy used to inhibit the growth of tumors, either alone or in association therapy, to decrease the overall tumor burden, without affecting normal tissue. Although radiotherapy is the standard procedure indicated to treat SCC [35], radioresistance is often observed [2]. In this context, there is urgent need to incorporate combined protocols to radiotherapy, with the goal to become a potentially curative option. In our current study, we designed an irradiation setup similar to routine clinical radiotherapy protocol, allowing evaluation of the cellular effects of X-rays on cell survival. Using our setup model, we demonstrated that the association therapy stately decreased SCC repopulation. We further demonstrated that the association therapy had the potential to minimize the irradiation toxicity, by keeping the surviving clonogenic cells to a lower rate, even under reduced total X-rays dose. Although, colony formation assay may involve events that reflect cell cycle progression, apoptosis, necrosis, and others, we had previously reported in liver cancer cells that nuclear $\mathrm{Ca}^{2+}$ buffering does not play a role in apoptosis [11]. Our previous and current data indicate that the beneficial effect of nuclear $\mathrm{Ca}^{2+}$ buffering in antitumor therapy is not due to its role in apoptosis, but instead due to changes caused in expression level of genes involved in the regulation of cell proliferation. Moreover, our findings could not be attributed to bystander effects, since in our irradiation model, in which tissue flasks are fulfilled with medium and immersed into water phantom, the dose applied to the cells monolayer was accurately calculated. This is distinct from the majority of the in vitro irradiation models in which tissue flasks containing cell monolayer are irradiated under air column. In this aspect, it is already demonstrated that when the thickness of the nutrient medium height above cells monolayer is lower than the electronic equilibrium depth (buildup depth) it is very difficult to determine the dose received by the cells [55]. The buildup depth is a function of energy photon beam [25] and as a result higher energy beam needs higher column of nutrient medium to assure complete electronic equilibrium in the cells position. When culture flasks are irradiated in air, because of the loss of lateral equilibrium, the buildup effect impinges the same uncertainty in the received dose by the cells, which is in the flask border, even if the column height of nutrient medium is sufficient to assure buildup. This is an important aspect to be considering when studying the effects of X-rays on cancer cells, since there are several evidences demonstrating changes in cell survival after irradiation, due to differences among energy spectrum and scattering caused by bystander effects $[22,56]$. 
Multiple factors have been shown to be involved in the cellular radiosensitivity of cancer cells [22,56]. For instance, it has been demonstrated that irradiation activates ADAM's members and induces cell growth through the release of EGFR ligand [33]. EGFR activation in turn, also mediates cytoprotective responses that reduces cell sensitivity to radiotherapy [4,57]. Moreover, it is also known that ADAM-17 over expression correlates with shorter survival rate of the patients due to several distinct growth and invasive pathways activated by this protease [58]. Indeed, in line with these data, we found that under our fractionated irradiation protocol in A431 cells, ADAM-17 expression and EGFR activation increased. However, $\mathrm{Ca}^{2+}$ buffering not only prevented the increase in ADAM-17 expression and EGFR activation induced by irradiation, but also, by itself, it was able to decrease the expression of EGFR bellow control levels. Although, characterization of the link between $\mathrm{Ca}^{2+}$ signals and changes in ADAM-17 and EGFR expression levels are beyond the scope of this study, our recent findings showed that $\mathrm{Ca}^{2+}{ }_{n}$ can regulate genes involved in cell proliferation, through a putative Elk-1 binding site present in the gene promoter region [12]. Indeed, Elk-1 transactivation was demonstrated to be dependent on nuclear rather than cytosolic $\mathrm{Ca}^{2+}[59]$. Therefore, it is possible that $\mathrm{Ca}^{2+}$ regulate ADAM-17 and EGFR expression through modulation of a $\mathrm{Ca}^{2+}$-dependent transcription factor activity.

Numerous EGFR blockers have been studied, as a therapeutic agent for the treatment of SCC [60]. Similarly, anti-ADAM-17 antibodies, as well as orally administrated ADAM inhibitor, have been used for treatment of solid tumors [60,61]. ADAM-17 and EGFR activate several physiological functions and systemic inhibition of these pathways represents a greater risk of multiple and severe side effects. The buffering of $\mathrm{Ca}^{2+}$ seems a promising strategy, since under our experimental condition, nucleoplasmic $\mathrm{Ca}^{2+}$ was only slightly reduced, and not completely chelated $[18,30]$. In this aspect, physiological functions mediated by $\mathrm{Ca}^{2+}$, at least in part, could be preserved. Moreover, using ionizing radiation concomitant with $\mathrm{Ca}^{2+}$ buffering, showed a superior outcome, compared to irradiation alone, and allowed to reduce the irradiation dose. Together, our findings indicate $\mathrm{Ca}^{2+}{ }_{\mathrm{n}}$ buffering in conjunction with radiotherapy as a therapeutic potential for the treatment of human squamous cell carcinoma.

\section{Author Contribution}

L.M.A., J.M.G., A.F.P.L., C.R.M., R.R.R., E.M.S.F., C.L.Z and M.F.L. designed research; L.M.A., J.M.G., A.M.C., S.Y., M.A.R., C.J.A., S.M.C and M.F.L. performed research; O.X.G, M.T.T.L and D.A.G. contributed new reagent or analytic tools; L.M.A., J.M.G., O.A.M.F. and M.F.L analyzed data; L.M.A., J.M.G., O.A.M.F. and M.F.L wrote the paper.

\section{Conflict of Interest}

All authors disclose that there is not conflict of interest as any financial and personal relationship with people or organizations, employment, consultancies, stock ownership, honoraria, patent registration that could influence this research inappropriately.

This research was supported by grants from Brazilian agencies FAPEMIG PRONEX, CNPq, CAPES and from United States Howard Hughes Medical Institute

\section{Acknowledgements}

We acknowledge Dr. Rogério Aguiar from Axial Image Center: Dr. Mateus T. Guerra and Dr. Michael H. Nathanson for carefully reading the manuscript; Cristina Armond, Ana B. Queiróz and Gilson Nogueira for their technical support. We also thanks Acrildam by platform construction, PDTISIFIOCRUZ and CEMELIUFMG for use their facilities. This research was supported by Grants from HHMI (USA), CAPES, CNPq, FAPEMIG and PRONEX (Brazil).

\section{References}

1. Ragin CC, Modugno F, Gollin SM (2007) The epidemiology and risk factors of head and neck cancer: a focus on human papillomavirus. J Dent Res 86:104 114
2. Diaz EM, Kies MS, Sturgis EM, Clayman L, Laramore GE, et al. (2006) Head and Neck: Cancer Medicine (7th edn), BC Decker, Hamilton, Ontário.

3. Affolter A, Fruth K, Brochhausen C, Schmidtmann I, Mann WJ, et al. (2011) Activation of mitogen-activated protein kinase extracellular signal-related kinase in head and neck squamous cell carcinomas after irradiation as part of a rescue mechanism. Head Neck 33: 1448-1457.

4. Schmidt-Ullrich RK, Contessa JN, Lammering G, Amorino G, Lin PS (2003) ERBB receptor tyrosine kinases and cellular radiation responses.Oncogene 22: $5855-5865$

5. Jonathan RA, Wijffels KI, Peeters W, de Wilde PC, Marres HA, et al. (2006) The prognostic value of endogenous hypoxia-related markers for head and neck squamous cell carcinomas treated with ARCON. Radiother Oncol 79: 288-297.

6. Paganetti $\mathrm{H}$ (2005) Changes in tumor cell response due to prolonged dose delivery times in fractionated radiation therapy. Int $\mathrm{J}$ Radiat Oncol Biol Phys 63: 892-900.

7. Ang KK, Berkey BA, Tu X, Zhang HZ, Katz R, et al. (2002) Impact of epidermal growth factor receptor expression on survival and pattern of relapse in patients with advanced head and neck carcinoma. Cancer Res 62: 7350-7356.

8. Liang K, Ang KK, Milas L, Hunter N, Fan Z (2003) The epidermal growth facto receptor mediates radioresistance. Int J Radiat Oncol Biol Phys 57: 246-254.

9. Todd DG, Mikkelsen RB (1994) lonizing radiation induces a transient increase in cytosolic free [Ca2+] in human epithelial tumor cells. Cancer Res 54: 5224 5230

10. Berridge MJ (2009) Inositol trisphosphate and calcium signalling mechanisms. Biochim Biophys Acta 1793: 933-940.

11. Rodrigues MA, Gomes DA, Leite MF, Grant W, Zhang L, et al. (2007) Nucleoplasmic calcium is required for cell proliferation. J Biol Chem 282 17061-17068.

12. Andrade V, Guerra M, Jardim C, Melo F, Silva W, et al. (2011) Nucleoplasmic calcium regulates cell proliferation through legumain. J Hepatol 55: 626-635.

13. Foo CC, Lee JS, Guilanno V, Yan X, Tan SH, et al. (2007) Squamous cell carcinoma and Bowen's disease of the skin in Singapore. Ann Acad Med Singapore 36: 189-193

14. Bonner JA, Trummell HQ, Willey CD, Plants BA, Raisch KP (2009) Inhibition of STAT-3 results in radiosensitization of human squamous cell carcinoma. Radiother Oncol 92: 339-344

15. Sah NK, Munshi A, Nishikawa T, Mukhopadhyay T, Roth JA, et al. (2003) Adenovirus-mediated wild-type p53 radiosensitizes human tumor cells by suppressing DNA repair capacity. Mol Cancer Ther 2: 1223-1231.

16. Schmidt-Ullrich RK, Mikkelsen RB, Dent P, Todd DG, Valerie K, et al. (1997) Radiation-induced proliferation of the human A431 squamous carcinoma cells is dependent on EGFR tyrosine phosphorylation. Oncogene 15: 1191-1197.

17. Xiao H, Zhang Q, Shen J, Bindokas V, Xing HR (2010) Pharmacologic inactivation of kinase suppressor of Ras1 sensitizes epidermal growth factor receptor and oncogenic Ras-dependent tumors to ionizing radiation treatment Mol Cancer Ther 9: 2724-2736.

18. Gomes DA, Rodrigues MA, Leite MF, Gomez MV, Varnai P, et al. (2008) c-Met must translocate to the nucleus to initiate calcium signals. J Biol Chem 283 4344-4351.

19. Franken NA, Rodermond HM, Stap J, Haveman J, van Bree C (2006) Clonogenic assay of cells in vitro. Nat Protoc 1: 2315-2319.

20. Riccardi C, Nicoletti I (2006) Analysis of apoptosis by propidium iodide staining and flow cytometry. Nat Protoc 1: 1458-1461.

21. Guerra MT, Fonseca EA, Melo FM, Andrade VA, Aguiar CJ, et al. (2011) Mitochondrial calcium regulates rat liver regeneration through the modulation of apoptosis. Hepatology 54: 296-306.

22. Hall EJ, Giaccia AJ (2006) Radiobiology for the Radiologist. (3rdedn), Lippincott Williams \& Wilkins, Philadelphia.

23. Yan D, Lockman D, Brabbins D, Tyburski L, Martinez A (2000) An off-line strategy for constructing a patient-specific planning target volume in adaptive treatment process for prostate cancer. Int J Radiat Oncol Biol Phys 48: 289302.

24. Kantzou I, Platoni K, Sandilos P, Gouliamos A, Kouvaris I, et al. (2011) 
Citation: Andrade LM, Geraldo JM, Gonçalves OX, Leite MTT, Catarina AM, et al. (2012) Nucleoplasmic Calcium Buffering Sensitizes Human Squamous Cell Carcinoma to Anticancer Therapy. J Cancer Sci Ther 4: 131-139. doi:10.4172/1948-5956.1000127

Conventional versus virtual simulation for radiation treatment planning of prostate cancer: final results. J BUON 16: 309-315

25. Khan FM (2010) The physics of radiation therapy. (4thedn), Lippincott Williams \& Wilkins, Philadelphia.

26. Yorke E, Gelblum D, Ford E (2011) Patient safety in external beam radiation therapy. AJR Am J Roentgenol 196: 768-772.

27. Purdy JA (2008) Principles of radiologic physics, dosimetry and treatmen planning: Principles and Practice of Radiation Oncology. (5thedn), Lippincott Williams \& Wilkins, Philadelphia.

28. Cerella C, Diederich M, Ghibelli L (2010) The dual role of calcium as messenger and stressor in cell damage, death, and survival. Int J Cell Biol 2010: 546163.

29. Várnai P, Lin X, Lee SB, Tuymetova G, Bondeva T, et al. (2002) Inositol lipid binding and membrane localization of isolated pleckstrin homology $(\mathrm{PH})$ domains. Studies on the PH domains of phospholipase C delta 1 and $\mathrm{p} 130 . \mathrm{J}$ Biol Chem 277: 27412-27422.

30. Rodrigues MA, Gomes DA, Andrade VA, Leite MF, Nathanson MH (2008) Insulin induces calcium signals in the nucleus of rat hepatocytes. Hepatology 48: 1621-1631.

31. Rosier JF, Michaux L, Ameye G, Cedervall B, Libouton JM, et al. (2003) The radioenhancement of two human head and neck squamous cell carcinomas by 2'-2' difluorodeoxycytidine (gemcitabine; $\mathrm{dFdC}$ ) is mediated by an increase in radiation-induced residual chromosome aberrations but not residual DNA DSBs. Mutat Res 527: 15-26.

32. Milas L, Fan Z, Andratschke NH, Ang KK (2004) Epidermal growth factor receptor and tumor response to radiation: in vivo preclinical studies. Int J Radiat Oncol Biol Phys 58: 966-971.

33. Blobel CP (2005) ADAMs: key components in EGFR signalling and development. Nat Rev Mol Cell Biol 6: 32-43.

34. Cai CQ, Peng Y, Buckley MT, Wei J, Chen F, et al. (2008) Epidermal growth factor receptor activation in prostate cancer by three novel missense mutations. Oncogene 27: 3201-3210.

35. Dirix P, Nuyts S (2010) Evidence-based organ-sparing radiotherapy in head and neck cancer. Lancet Oncol 11: 85-91.

36. Ramaekers BL, Joore MA, Grutters JP, van den Ende P, Jong J, et al. (2011) The impact of late treatment-toxicity on generic health-related quality of life in head and neck cancer patients after radiotherapy. Oral Oncol 47: 768-774.

37. Allbritton NL, Oancea E, Kuhn MA, Meyer T (1994) Source of nuclear calcium signals. Proc Natl Acad Sci U S A 91: 12458-12462.

38. Brini M, Murgia M, Pasti L, Picard D, Pozzan T, et al. (1993) Nuclear Ca2+ concentration measured with specifically targeted recombinant aequorin. EMBO J 12: 4813-4819.

39. Hennager DJ, Welsh MJ, DeLisle S (1995) Changes in either cytosolic or nucleoplasmic inositol 1,4,5-trisphosphate levels can control nuclear Ca2+ concentration. J Biol Chem 270: 4959-4962.

40. Lipp P, Thomas D, Berridge MJ, Bootman MD (1997) Nuclear calcium signalling by individual cytoplasmic calcium puffs. EMBO J 16: 7166-7173.

41. Gerasimenko OV, Gerasimenko JV, Tepikin AV, Petersen OH (1995) ATPdependent accumulation and inositol trisphosphate- or cyclic ADP-ribosemediated release of $\mathrm{Ca} 2+$ from the nuclear envelope. Cell 80: 439-444.

42. Malviya AN, Rogue P, Vincendon G (1990) Stereospecific inositol 1,4,5 [32P] trisphosphate binding to isolated rat liver nuclei: evidence for inosito trisphosphate receptor-mediated calcium release from the nucleus. Proc Nat Acad Sci U S A 87: 9270-9274.

43. Stehno-Bittel L, Perez-Terzic C, Clapham DE (1995) Diffusion across the nuclear envelope inhibited by depletion of the nuclear $\mathrm{Ca} 2+$ store. Science 270: $1835-1838$

44. Echevarría W, Leite MF, Guerra MT, Zipfel WR, Nathanson MH (2003) Regulation of calcium signals in the nucleus by a nucleoplasmic reticulum. Nat Cell Biol 5: 440-446.

45. Santella L, Kyozuka K (1997) Effects of 1-methyladenine on nuclear Ca2+ transients and meiosis resumption in starfish oocytes are mimicked by the nuclear injection of inositol 1,4,5-trisphosphate and cADP-ribose. Cell Calcium 22: $11-20$.
46. Cocco L, Gilmour RS, Ognibene A, Letcher AJ, Manzoli FA, et al. (1987) Synthesis of polyphosphoinositides in nuclei of Friend cells. Evidence for polyphosphoinositide metabolism inside the nucleus which changes with cell differentiation. Biochem J 248: 765-770.

47. Martelli AM, Gilmour RS, Bertagnolo V, Neri LM, Manzoli L, et al. (1992) Nuclear localization and signalling activity of phosphoinositidase $C$ beta in Swiss 3 T3 cells. Nature 358: 242-245.

48. Guatimosim S, Amaya MJ, Guerra MT, Aguiar CJ, Goes AM, et al. (2008) Nuclear Ca2+ regulates cardiomyocyte function. Cell Calcium 44: 230-242.

49. Koppler P, Matter N, Malviya AN (1993) Evidence for stereospecific inosito $1,3,4,5-[3 \mathrm{H}]$ tetrakisphosphate binding sites on rat liver nuclei. Delineating inositol 1,3,4,5-tetrakisphosphate interaction in nuclear calcium signaling process. J Biol Chem 268: 26248-26252.

50. Mak DO, Foskett JK (1994) Single-channel inositol 1,4,5-trisphosphate receptor currents revealed by patch clamp of isolated Xenopus oocyte nuclei. $J$ Biol Chem 269: 29375-29378.

51. Malviya AN (1994) The nuclear inositol 1,4,5-trisphosphate and inosito 1,3,4,5-tetrakisphosphate receptors. Cell Calcium 16: 301-313.

52. Stehno-Bittel L, Lückhoff A, Clapham DE (1995) Calcium release from the nucleus by InsP3 receptor channels. Neuron 14: 163-167.

53. Roderick HL, Cook SJ (2008) Ca2+ signalling checkpoints in cancer: remodelling $\mathrm{Ca} 2+$ for cancer cell proliferation and survival. Nat Rev Cance 8: 361-375.

54. Lagoudakis L, Garcin I, Julien B, Nahum K, Gomes DA, et al. (2010) Cytosolic calcium regulates liver regeneration in the rat. Hepatology 52: 602-611.

55. Severin E, Kronholz HL, Köhnlein W, Göhde W (2005) Dosimetry of soft x-rays in thin liquid layers. Phys Med Biol 50: 1459-1467.

56. Bewes JM, Suchowerska N, Jackson M, Zhang M, McKenzie DR (2008) The radiobiological effect of intra-fraction dose-rate modulation in intensity modulated radiation therapy (IMRT). Phys Med Biol 53: 3567-3578.

57. Nowsheen S, Bonner JA, Lobuglio AF, Trummell H, Whitley AC, et al. (2011) Cetuximab augments cytotoxicity with poly (adp-ribose) polymerase inhibition in head and neck cancer. PLoS One 6: e24148.

58. Kornfeld JW, Meder S, Wohlberg M, Friedrich RE, Rau T, et al. (2011) Overexpression of TACE and TIMP3 mRNA in head and neck cancer: association with tumour development and progression. Br J Cancer 104:138 145

59. PusI T, Wu JJ, Zimmerman TL, Zhang L, Ehrlich BE, et al. (2002) Epidermal growth factor-mediated activation of the ETS domain transcription factor Elk-1 requires nuclear calcium. J Biol Chem 277: 27517-27527.

60. Nestor M, Sundström M, Anniko M, Tolmachev V (2011) Effect of cetuximab in combination with alpha-radioimmunotherapy in cultured squamous cell carcinomas. Nucl Med Biol 38: 103-112.

61. Witters L, Scherle P, Friedman S, Fridman J, Caulder E, et al. (2008) Synergistic inhibition with a dual epidermal growth factor receptor/HER-2/neu tyrosine kinase inhibitor and a disintegrin and metalloprotease inhibitor. Cancer Res 68: 7083-7089. 